\title{
Disposisi Berpikir Terbuka Secara Aktif: Definisi, Pengukuran, dan Kaitannya dengan Prestasi Akademik
}

\author{
Actively Open-Minded Thinking: Definition, Assessment, and Its Relation with \\ Academic Performance
}

\author{
Anindito Aditomo \\ Fakultas Psikologi Universitas Surabaya, Surabaya
}

\begin{abstract}
This study seeks to evaluate the validity of a scale intended to measure actively open-minded thinking (AOT), and to explore whether AOT can predict academic performance. The Rasch model was applied to evaluate the scale's construct validity through the mirt package in $R$. Scale validation was based upon a sample of university students in Surabaya $(\mathrm{N}=424)$, while regression analysis to predict academic achievement was based on a sub-sampel for which data was available $(n=220)$. Rasch analysis results suggested that the 10-item self-report scale had good construct validity, especially when measuring participants from the lower end of the trait level spectrum. AOT was found to be positively and moderately correlated with conscientiousness and openness to experience. AOT also predicted higher performance in a course which assessed students' ability to analyse and evaluate arguments, as well as overall performance assessed by their grade point average (GPA) 18 months later. These results suggest that AOT is an important variable that can be adequately measured using a self-report instrument. Further work should focus on creating items which are more difficult to endorse.
\end{abstract}

Keywords: Thinking disposition, intellectual character, item-response theory, Big 5 personality, academic achievement

\begin{abstract}
Abstrak: Penelitian ini bertujuan mengevaluasi validitas sebuah skala disposisi berpikir terbuka secara aktif, serta mengeksplorasi apakah disposisi tersebut dapat memprediksi prestasi akademik. Validasi skala dilakukan pada sampel mahasiswa sebuah universitas di Surabaya $(\mathrm{N}=424)$, sedangkan regresi untuk memprediksi prestasi akademik dilakukan pada sub-sampel $(n=220)$. Validasi dilakukan dengan model Rasch menggunakan paket mirt di program R. Hasil pemodelan Rasch menunjukkan bahwa skala disposisi berpikir terbuka-aktif memiliki validitas konstruk yang baik, terutama untuk sampel dengan tingkat disposisi yang rendah. Disposisi berpikir terbuka-aktif juga terbukti berkorelasi positif moderat dengan dimensi kepribadian openness to experience dan conscientiousness. Selain itu, disposisi tersebut juga terbukti memprediksi prestasi belajar pada mata kuliah yang mengukur kemampuan analisis/evaluasi argumen, serta pada indeks prestasi secara keseluruhan 18 bulan kemudian. Dalam disimpulkan bahwa disposisi berpikir terbuka-aktif merupakan konstruk yang perlu diperhatikan oleh peneliti maupun praktisi pendidikan. Pengembangan skala perlu diarahkan pada penulisan butir-butir yang memiliki tingkat kesulitan lebih tinggi.
\end{abstract}

Kata kunci: disposisi berpikir, karakter intelektual, teori butir-respons, kepribadian Big 5, prestasi akademik.

Korespondensi tentang artikel ini dapat dialamatkan kepada Anindito Aditomo melalui email: aditomo@staff.ubaya.ac.id. 
Kemampuan berpikir kritis (critical thinking) dan tingkat tinggi (higher-order thinking) adalah bagian esensial dari kompetensi Abad 21 (Dwyer, Hogan, \& Stewart, 2014). Perkembangkan teknologi informasi membuat semakin banyak persoalan rutin tertangani oleh komputer dan robot. Di sisi lain, perkembangan yang sama juga telah mendorong terciptanya ekologi informasi yang kompleks, serba cepat, dan penuh ketidakpastian. Pada level personal, kemampuan berpikir mandiri dan belajar sepanjang hayat menjadi penting bagi individu yang ingin beradaptasi dengan lingkungan dan masalah-masalah kompleks yang baru (Griffin, McGaw, \& Care, 2012). Pada level sosial, kemampuan mencerna dan mengevaluasi informasi untuk kemudian mengambil keputusan secara bijak mengenai berbagai isu publik menjadi salah satu landasan bagi kehidupan demokrasi yang sehat (Weinstein, 1991).

Berpikir kritis bukan hanya soal memiliki keterampilan untuk menganalisis dan mengevaluasi informasi. Berpikir kritis juga melibatkan kemauan untuk menerapkan keterampilan-keterampilan kognitif tersebut (Facione, 2000). Kegagalan berpikir lebih sering terjadi karena individu tidak menyadari bahwa sebuah situasi memerlukan penerapan critical thinking (Perkins \& Tishman, 1998). Seseorang yang terampil menganalisis pergerakan harga saham untuk keperluan bisnis, misalnya, belum tentu menerapkan keterampilan tersebut ketika membaca berita sosialpolitik di media sosial. Karena itu ia bisa terperdaya informasi palsu (hoaxes) atau mengambil keputusan yang tidak rasional (Stanovich, West, \& Toplak, 2013). Sisi afektif yang mendorong individu untuk menerapkan keterampilan kognitif secara sadar dan konsisten disebut sebagai disposisi berpikir (thinking dispositions).

Artikel ini terfokus pada disposisi yang disebut sebagai actively open-minded thinking alias berpikir terbuka secara aktif (selanjutnya disingkat BTA). Esensi dari disposisi BTA dapat dipahami dalam konteks proses berpikir ketika menghadapi permasalahan yang kompleks. Dalam konteks tersebut, seseorang perlu mencari kemungkinan solusi atau jawaban, serta informasi yang bisa digunakan untuk mengevaluasi tiap kemungkinan tersebut (Barzilai \& Chinn, 2018). Individu dengan disposisi BTA yang kuat akan secara sengaja ("aktif") berupaya mencari beragam kriteria, kemungkinan solusi, dan bukti-bukti yang berseberangan dengan pendapat pribadinya (Baron, 2018). Dengan demikian, ciri utama BTA bukan lama atau kerasnya seseorang berpikir, melainkan arah dan tujuan proses berpikirnya. Proses pencarian dengan ciri seperti ini dapat menghasilkan simpulan yang mungkin membuat individu merevisi atau menggugurkan pendapat yang sebelumnya ia yakini.

Ada beberapa disposisi berpikir yang mirip namun perlu dibedakan dari BTA. Misalnya, need for cognition (NFC) yang mencerminkan kesukaan mengerahkan usaha kognitif (Jebb, Saef, Parrigon, \& Woo, 2016). NFC berbicara tentang besarnya usaha kognitif, sedangkan BTA lebih terkait dengan arah dan tujuan berpikir. Seseorang bisa saja memiliki NFC tinggi dan BTA yang rendah. Dalam kasus tersebut, individu akan senang mengerahkan banyak energi untuk berpikir, namun dengan tujuan yang mendukung pendapat pribadinya. Konstruk lain yang mirip dengan BTA adalah sifat terbuka terhadap pengalaman baru (openness to new experience) yang menjadi bagian dari model kepribadian Big 5 (Woo et al., 2014). Fokus sifat ini adalah pada kebaruan. Individu dengan openness tinggi menikmati sensasi pengalaman baru. Berbeda dari hal itu, individu dengan disposisi BTA yang kuat akan menghargai informasi bukan karena kebaruannya, melainkan karena potensinya untuk memperdalam pemahaman.

BTA terbukti sebagai disposisi yang penting dalam proses mengevaluasi argumen dan pengambilan keputusan. Ketika 
diminta mengevaluasi argumen tentang isu sosial-politik yang kontroversial (misalnya, isu pajak atau cara menangani kejahatan), individu dengan disposisi BTA yang kuat juga lebih mampu mengesampingkan keyakinan pribadi sehingga menghasilkan evaluasi yang lebih akurat (Stanovich \& West, 1997). Misalnya, ketika mengevaluasi argumen yang lemah tentang hukuman mati, individu dengan disposisi BTA tinggi akan bisa mengenali kelemahan argumen tersebut, meski ia secara pribadi menyetujuinya. Penelitian lain menemukan bahwa ketika diminta memecahkan teka-teki, individu dengan BTA yang kuat cenderung lebih cermat dalam memproses informasi dan karena itu lebih berhasil memperoleh pemecahan yang tepat (Haran, Ritov, \& Mellers, 2013). Disposisi BTA juga ditengarai menjelaskan mengapa individu tertentu mudah mempercayai berita palsu (Bronstein, Pennycook, Bear, Rand, \& Cannon, 2018).

Belum banyak riset yang menelaah peran BTA dalam konteks akademik. Secara teoretis BTA memiliki peran penting dalam proes belajar. Siswa yang memiliki sifat berpikir terbuka secara aktif seharusnya juga lebih termotivasi untuk menggali informasi secara mendalam untuk memahami permasalahan. Hal ini berlaku terutama untuk materi-materi kuliah yang menuntut seseorang merevisi pemahaman awamnya agar sesuai dengan konsepsi yang lebih ilmiah. Misalnya, orang awam kerap memiliki konsepsi yang keliru tentang penyakit jiwa. Ketika mempelajari fenomena tersebut secara ilmiah, mahasiswa yang mau secara aktif membaca beragam informasi, termasuk yang bertentangan dengan pandangan awamnya, akan lebih mendapat pema-haman lebih mendalam.

Saat ini belum ada instrumen untuk mengukur disposisi BTA dalam bahasa Indonesia. Karena itu, tujuan utama penelitian ini adalah untuk mengembangkan dan mengevaluasi validitas sebuah instru- men self-report untuk mengukur disposisi BTA. Validitas dievaluasi berdasarkan dua jenis bukti, yakni bukti terkait struktur internal skala, dan bukti mengenai korelasi hasil pengukuran dengan variabel lain.

Bukti mengenai struktur internal skala diperoleh dari analisis dengan pendekatan teori respons butir (itemresponse theory/IRT). Asumsi dasar IRT adalah bahwa respon seorang individu terhadap sebuah butir tes atau skala ditentukan oleh interaksi antara karakteristik butir tersebut dengan tingkat (tinggi-rendahnya atau kuat-lemahnya) atribut yang dimiliki oleh individu tersebut (Baker \& Kim, 2017). Dengan demikian, model-model IRT pada dasarnya adalah formula statistik mengenai probabilitas seorang individu memberi respon tertentu terhadap sebuah pertanyaan atau butir tes atau skala.

Melalui pemodelan yang memperhitungkan atribut butir dan individu secara simultan, IRT mengatasi kelemahan pendekatan klasik (classical test theory) yang beroperasi menggunakan skor mentah (Wu, Tam, \& Jen, 2016). Dalam pengukuran sosial-psikologis, skor mentah yang dihasilkan skala/tes masih bersifat ordinal. Karena itu, hasil pengukuran dengan pendekatan klasik hanya bisa mengurutkan individu, namun tidak bisa membuat perbandingan yang presisi tentang jarak antar individu tersebut. Sebagai ilustrasi, misalkan tiga siswa mendapat skor mentah 50, 60, dan 80 pada sebuah tes kemampuan berhitung. Skor tersebut mencerminkan urutan kemampuan berhitung, namun tidak mencerminkan jarak objektif antar ketiganya. Dengan kata lain, kita tidak bisa mengatakan bahwa perbedaan kemampuan berhitung siswa pertama dan kedua lebih kecil dibanding perbedaan antara siswa kedua dan ketiga. Perbandingan jarak antar individu menuntut skor pada level interval, seperti yang dihasilkan oleh pemodelan IRT (Wu et al., 2016). Dari berbagai pendekatan IRT yang ada, penelitian ini menggunakan pendekatan Rasch (Bond \& 
Fox, 2015). Berbeda dari pendekatan IRT lain, Rasch mengasumsikan adanya model ideal dan mengevaluasi seberapa baik data mencerminkan model ideal tersebut.

Melengkapi analisis IRT, penelitian ini juga mengevaluasi validitas skala BTA berdasar pola korelasinya dengan variabel lain yang relevan. Untuk melihat validitas diskriminan, skor skala BTA akan dikorelasikan dengan skor sifat terbuka terhadap openness to new experience (Woo et al., 2014) dan conscientiousness. Seperti telah diuraikan di atas, openness adalah dimensi kepribadian yang secara konseptual memiliki kedekatan dengan BTA. Karena itu, kedua skor seharusnya berkorelasi positif pada level moderat: tidak rendah, namun juga tidak terlalu tinggi. Conscientiousness merujuk pada kecenderungan untuk melakukan perencanaan, mengendalikan impuls, dan menunda kesenangan demi mencapai tujuan (Roberts, Jackson, Fayard, Edmonds, \& Meints, 2009). Di sisi lain, disposisi BTA juga mencakup kemauan mengendalikan diri dalam hal pengambilan simpulan dan keputusan. Karena itu BTA juga seharusnya berkorelasi positif dengan conscientiousness (meski tidak sekuat dengan openness).

Selain mengevaluasi validitas skala, penelitian ini juga bertujuan untuk mengeksplorasi peran disposisi BTA pada konteks akademik. Secara lebih spesifik, penelitian ini hendak menguji apakah disposisi BTA dapat memprediksi prestasi akademik. Secara teoretis, BTA seharusnya berkorelasi dengan kinerja untuk pekerjaan yang menuntut individu berpikir kritis dan tingkat tinggi. Hal ini seharusnya berlaku juga untuk konteks akademik, setidaknya untuk mata kuliah yang menuntut aplikasi daya nalar. Analisis prediktif ini dilakukan dengan mengendalikan sifat-sifat kepribadian openness to experience dan conscientiousness yang diketahui sebagai variabel psikologis yang secara konsisten memprediksi prestasi akademik (Richardson, Abraham, \& Bond, 2012).
Dengan demikian, pertanyaan yang dikaji dalam penelitian ini adalah sebagai berikut:

(1) Seberapa kuat validitas skala disposisi BTA ditinjau berdasarkan model Rasch?

(2) Apakah korelasi skor disposisi BTA dengan sifat kepribadian openess to experience sejalan dengan teori?

(3) Apakah skor disposisi BTA dapat memprediksi prestasi akademik, setelah mengendalikan sifat-sifat kepribadian openness dan conscientiousness?

\section{Metode}

Sampel

Pemodelan Rasch (analisis IRT) didasarkan pada 424 mahasiswa program psikologi yang diperoleh melalui convenience sampling. Usia subjek bergerak antara 16 sampai 22 tahun, dengan rata-rata 18.7 tahun. Sebagian besar subjek $(77.8 \%)$ adalah perempuan. Sekitar separuh $(48.1 \%)$ adalah mahasiswa semester 1, sedangkan sisanya adalah mahasiswa semester 5. Analisis hubungan antar variabel (disposisi BTA, dimensi kepribadian, dan prestasi akademik) dilakukan pada sub-sampel mahasiswa semester 1 .

\section{Pengumpulan Data}

Data variabel demografis dan psikologis dikumpulkan melalui kuesioner daring (online) yang dibuat menggunakan Googleform. Subjek diminta mengisi kuesioner pada minggu pertama semester gasal tahun ajaran 2017/2018. Prestasi akademik diukur berdasarkan nilai mata kuliah logika (yang mencerminkan kemampuan menganalisis argumen), serta indeks prestasi kumulatif (yang mencerminkan hasil belajar secara lebih menyeluruh). Nilai mata kuliah logika diperoleh pada akhir semester gasal 2017/2018, 
sedangkan IPK diperoleh pada akhir semester gasal 2018/2019.

Bagian utama kuesioner tersusun atas skala berpikir terbuka secara aktif (BTA) dan Big Five Inventory yang mengukur openness to experience, conscientiousness, extraversion, agreeableness, dan neuroticism. Dari lima dimensi kepribadian tersebut, hanya keterbukaan (openness) dan conscientious-ness yang digunakan dalam penelitian ini. Skala keterbukaan terdiri dari 10 butir (contoh: "Ingin tahu banyak hal unik"), sedangkan skala conscientiousness terdiri dari 9 butir (contoh: "Mengerjakan tugas dengan teliti"), dengan pilihan jawaban bergerak dari 1 ("Sangat tidak setuju") sampai 6 ("Sangat setuju").

Skala BTA terdiri dari 10 butir skala yang memiliki pilihan antara 1 ("Sangat tidak setuju"), 2 ("Tidak setuju"), 3 ("Netral"), 4 ("Setuju"), dan 5 ("Sangat setuju"). Berdasarkan konseptualisasi yang diajukan Baron (2017) dan Haran et al. (2013), penulis menyimpulkan adanya tiga indikator utama disposisi BTA (lihat Tabel
1), yaitu (a) kemauan merevisi pendapat yang dianggap benar ketika ada bukti yang menggugurkan pendapat tersebut, (b) kecenderungan mencari informasi dan perspektif yang ber-beda-beda tentang sebuah isu atau topik/ problem, dan (c) sifat mementingkan akurasi dan pemahaman yang menyeluruh, dengan risiko menunda pengambilan keputusan. Kaitan antara indikator dan butir skala BTA ditampilkan di Lampiran.

\section{Analisis Data}

Sebagian besar analisis dilakukan dengan program $\mathrm{R}$ yang dijalankan melalui R-Studio (R Core Team, 2018). Pemodelan Rasch dilakukan dengan paket mirt (Chalmers, 2012). Model yang digunakan adalah partial credit model, sebuah model Rasch untuk butir dengan pilihan skor polytomous (tidak hanya 0 dan 1 ) seperti skala Likert (Wu et al., 2016). Rating scale model tidak digunakan karena mensyaratkan rentang pilihan jawaban yang sama untuk semua butir.

Tabel 1. Aspek dan butir skala disposisi berpikir aktif secara terbuka (BTA)

\begin{tabular}{|c|c|c|}
\hline Butir & Isi butir & Aspek \\
\hline bta1 & $\begin{array}{l}\text { Saya senang dengan informasi yang mendorong saya memikirkan } \\
\text { ulang pendapat saya. }\end{array}$ & A (revisi keyakinan) \\
\hline bta2 & $\begin{array}{l}\text { Saya senang mendiskusikan hal-hal kontroversial yang bisa } \\
\text { membuat saya memikirkan ulang kebenaran yang saya yakini. }\end{array}$ & A (revisi keyakinan) \\
\hline bta3 & $\begin{array}{l}\text { Dalam mengambil keputusan, kita harus selalu } \\
\text { mempertimbangkan hal-hal yang bertolak belakang dengan } \\
\text { pendapat kita. }\end{array}$ & $\begin{array}{l}\text { B (pencarian informasi } \\
\text { yang beragam) }\end{array}$ \\
\hline bta4 & $\begin{array}{l}\text { Dalam memikirkan sebuah masalah, saya selalu } \\
\text { mempertimbangkan pendapat-pendapat yang berseberangan. }\end{array}$ & $\begin{array}{l}\text { B (pencarian informasi } \\
\text { yang beragam) }\end{array}$ \\
\hline bta5 & $\begin{array}{l}\text { Saya selalu berusaha melihat dari semua sudut pandang sebelum } \\
\text { membuat keputusan. }\end{array}$ & $\begin{array}{l}\text { B (pencarian informasi } \\
\text { yang beragam) }\end{array}$ \\
\hline bta6 & $\begin{array}{l}\text { Dalam berpendapat, saya selalu mempertimbangkan berbagai } \\
\text { bukti yang ada. }\end{array}$ & $\begin{array}{l}\text { B (pencarian informasi } \\
\text { yang beragam) }\end{array}$ \\
\hline bta7 & $\begin{array}{l}\text { Jika masih banyak hal yang tidak pasti, kita harus mempelajari } \\
\text { lebih lanjut situasinya sebelum menetapkan solusi. }\end{array}$ & $\begin{array}{l}\mathrm{C} \text { (menunda demi } \\
\text { akurasi) }\end{array}$ \\
\hline bta8 & $\begin{array}{l}\text { Sebelum menetapkan solusi, saya harus memahami masalahnya } \\
\text { secara menyeluruh. }\end{array}$ & $\begin{array}{l}\mathrm{C} \text { (menunda demi } \\
\text { akurasi) }\end{array}$ \\
\hline bta9 & $\begin{array}{l}\text { Kita harus memikirkan sesuatu dengan baik sebelum } \\
\text { memutuskan untuk percaya atau tidak. }\end{array}$ & $\begin{array}{l}\mathrm{C} \text { (menunda demi } \\
\text { akurasi) }\end{array}$ \\
\hline bta10 & $\begin{array}{l}\text { Lebih baik bertahan pada prinsip yang kita yakini daripada } \\
\text { berpikiran terbuka. [Catatan: butir unfavourable, di-skor terbalik] }\end{array}$ & A (revisi keyakinan) \\
\hline
\end{tabular}


Dalam penelitian ini, meski tersedia 5 pilihan jawaban untuk setiap butir, pada sebagian butir opsi pilihan paling rendah (Sangat tidak setuju) tidak dipilih oleh responden, sehingga secara empiris butirbutir tersebut hanya memiliki 4 pilihan jawaban.

Langkah pertama dalam analisis IRT adalah mengevaluasi asumsi bahwa skala BTA mengukur 1 dimensi. Asumsi unidimensionalitas dievaluasi dengan pengecekan scree plot nilai Eigen dari analisis faktor eksploratoris dengan korelasi polychoric. Selanjutnya, kualitas skala dievaluasi berdasarkan kecocokan (fit) antara pola respon empiris dengan pola yang diprediksi oleh model teoretis. Dalam pemodelan Rasch, indikator kecocokan yang lazim digunakan adalah rasio chi-square yang disebut infit dan outfit. Selain itu, nilai threshold untuk tiap pilihan jawaban digunakan untuk mengevaluasi masing-masing butir secara lebih detil.

Skor disposisi BTA tiap responden berdasarkan pemodelan Rasch kemudian digunakan dalam analisis korelasi dan regresi untuk melihat kaitannya dengan openness to experience dan prestasi akademik. Skor openness to experience serta conscientiousness juga diperoleh berdasarkan pemodelan Rasch. Dengan demikian, kedua variabel ini diwakili oleh skor logit yang bersifat interval. Grafik dibuat dengan paket ggplot2 (Wickham, 2016).

\section{Hasil}

\section{Statistik deskriptif}

Hasil analisis data menghasilkan rentang, skor rata-rata, dan simpangan baku disposisi BTA, variabel kepribadian, dan prestasi akademik ditampilkan di Tabel 2.

Table 2. Statistik deskriptif

\begin{tabular}{lcccc}
\hline \multicolumn{1}{c}{ Variabel } & Minimum & Maksimum & Rata-rata & Simpangan baku \\
\hline Disposisi BTA & -2.298 & 2.329 & 0.011 & 0.848 \\
Conscientiousness & -1.879 & 2.254 & -0.012 & 0.572 \\
Openness to experience & -2.308 & 2.426 & -0.005 & 0.800 \\
Indeks Prestasi (IPK) & 0.00 & 3.98 & 3.23 & .49 \\
Nilai Logika & 0.00 & 100.00 & 71.81 & 14.76 \\
\hline
\end{tabular}

Keterangan: Data disposisi BTA, Conscientiousness, dan Openness ditampilkan dalam skor logit, sedangkan IPK dan nilai Logika merupakan skor komposit.

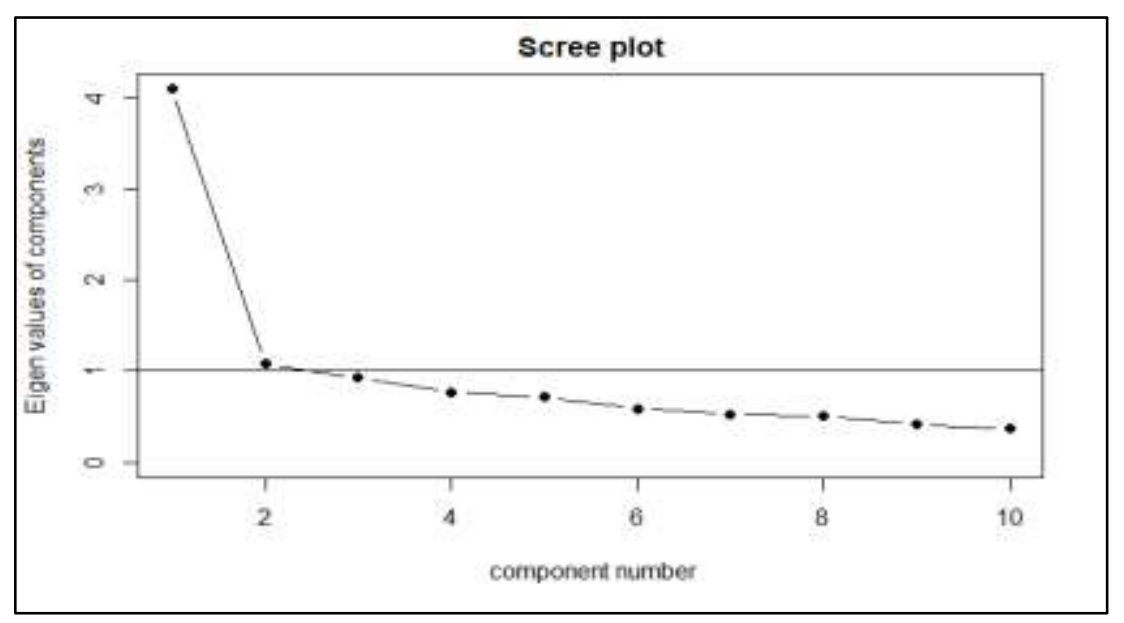

Gambar 1. Nilai Eigen hasil analisis faktor ekploratoris dengan korelasi polychoric antar butir 
Dimensionalitas skala. Analisis faktor eksploratoris menunjukkan dua faktor yang memiliki nilai Eigen lebih dari 1. Namun demikian, nilai Eigen faktor kedua hanya sedikit di atas 1 , dan scree plot menunjukkan bahwa selisih antara nilai Eigen faktor pertama dan kedua jauh lebih besar dibanding selisih antara faktor kedua dan ketiga (Gambar 1). Selain itu, analisis faktor konfirmatori menunjukkan bahwa data memiliki fit (kecocokan) yang baik dengan model 1 faktor, dengan nilai RMSEA yang rendah (0.011), nilai CFI (0.995) serta TLI (0.998) yang tinggi. Dengan demikian, asumsi unidimensionalitas dianggap dapat dipertahankan. Respon pada 8 dari 10 butir terlihat memiliki kaitan erat dengan faktor laten (varians yang dijelaskan oleh faktor laten berkisar $32.3 \%$ s.d. $48.6 \%$ ). Untuk butir aot2, varians yang dijelaskan faktor laten adalah $26.7 \%$, sedangkan untuk aot10 angka tersebut hanyalah $5.7 \%$.

Kecocokan (fit) butir. Statistik outfit dan infit tiap butir ditampilkan di Tabel 3. Semakin mendekati angka 1 (untuk nilai mean-square outfit/infit) atau 0 (untuk nilai $\mathrm{z}$ atau outfit/infit terstandard), semakin baik kecocokan pola respon empiris terhadap butir dengan pola teoretis yang diprediksi oleh model Rasch. Rentang outfit/infit yang masih dapat diterima adalah 0.5 s.d. 1.5 untuk nilai mean-square dan -1.9 s.d. 2.9 untuk nilai z/terstandard (Lincare, 2002). Berdasarkan nilai meansquare, hanya butir aot10 yang pola res-

Tabel 3. Indeks kecocokan (fit) butir

\begin{tabular}{llccr}
\hline Butir & Outfit & z.outfit & Infit & z.infit \\
\hline bta1 & 0.893 & -1.344 & 0.901 & -1.184 \\
bta2 & 0.966 & -0.467 & 0.976 & -0.320 \\
bta3 & 0.927 & -0.992 & 0.921 & -1.059 \\
bta4 & 0.862 & -1.927 & 0.875 & -1.695 \\
bta5 & 0.916 & -1.231 & 0.921 & -1.146 \\
bta6 & 0.856 & -1.875 & 0.870 & -1.574 \\
bta7 & 0.848 & -2.196 & 0.858 & -2.015 \\
bta8 & 0.830 & -2.426 & 0.850 & -2.028 \\
bta9 & 0.859 & -2.167 & 0.885 & -1.706 \\
bta10 & 1.307 & 4.127 & 1.277 & 3.707 \\
\hline
\end{tabular}

Tabel 4. Lokasi/tingkat kesulitan butir dan ambang batas pilihan (rating threshold)

\begin{tabular}{lccccc}
\hline \multirow{2}{*}{ Butir } & \multirow{2}{*}{ Lokasi butir } & \multicolumn{4}{c}{ Ambang pilihan (rating) } \\
\cline { 3 - 6 } & & b1 & b2 & b3 & b4 \\
\hline bta1 & -1.535 & -1.860 & -4.072 & -1.715 & 1.508 \\
bta2 & -1.470 & -3.848 & -2.050 & -1.076 & 1.095 \\
bta3 & -1.685 & -4.299 & -2.231 & -1.450 & 1.242 \\
bta4 & -1.658 & -3.701 & -3.000 & -1.407 & 1.477 \\
bta5 & -1.220 & NA & -2.667 & -1.509 & 0.516 \\
bta6 & -1.918 & -2.932 & -3.249 & -2.433 & 0.943 \\
bta7 & -1.836 & NA & -3.952 & -2.493 & 0.937 \\
bta8 & -1.744 & NA & -2.792 & -2.984 & 0.543 \\
bta9 & -1.997 & NA & -3.810 & -2.603 & 0.422 \\
bta10 & -0.923 & -2.749 & -2.032 & -0.299 & 1.390 \\
\hline
\end{tabular}


ponnya kurang cocok dengan model. Butir aot10 tetap dipertahankan karena nilai mean-square outfit/infit-nya mendekati ideal (Lincare, 2002). Analisis yang dilakukan tanpa butir aot10 menghasilkan temuan yang tidak berbeda secara substantif.

Rating scale dan tingkat kesulitan butir. Analisis Rasch dengan partial credit model menghasilkan threshold (nilai ambang) yang menunjukkan level theta (tingkat diposisi BTA) yang diperlukan untuk beralih dari satu opsi respon ke opsi berikutnya. Untuk butir dengan 5 opsi respon seperti dalam skala BTA, terdapat empat nilai ambang. Pada Tabel 4, nilai ambang tersebut diberi label $b 1$ (level theta peralihan dari "Sangat tidak setuju" ke "Tidak setuju"), b2 (dari "Tidak setuju" ke "Netral"), b3 (dari "Netral" ke "Setuju"), dan $b 4$ (dari "Setuju" ke "Sangat setuju"). Pada butir bta5, bta7, dan bta8 hanya muncul 3 nilai ambang karena tidak ada responden yang memilih opsi "Sangat tidak setuju".
Nilai ambang seharusnya secara berurutan menjadi lebih besar (lebih positif), dengan selisih minimal 1 skor logit (Lincare, 1999). Pada butir bta1, bta6, dan bta8, sebagian nilai ambang tidak sesuai urutan yang diharapkan. Misalnya, pada bta1 nilai ambang b1 (yakni -1.860) justru lebih besar dibanding b2 (yakni -4.072). Hal ini menunjukkan bahwa probabilitas terpilihnya opsi jawaban "Tidak setuju" amat rendah dan tidak pernah berada di atas probabilitas opsi jawaban lainnya. Hal ini terlihat pada Gambar 2, di mana garis yang mewakili P2 (opsi kedua, yakni "Tidak setuju") selalu berada di bawah garis probabilitas opsi-opsi lainnya.

Nilai ambang seluruh butir ditampilkan secara visual pada Gambar 3. Sumbu horizontal untuk tiap butir mewakili tingkat kesulitan peralihan opsi jawaban. Terlihat bahwa letak nilai ambang sering berdekatan (misalnya, pada butir bta1, bta6, dan bta8).

\section{Butir BTA1}

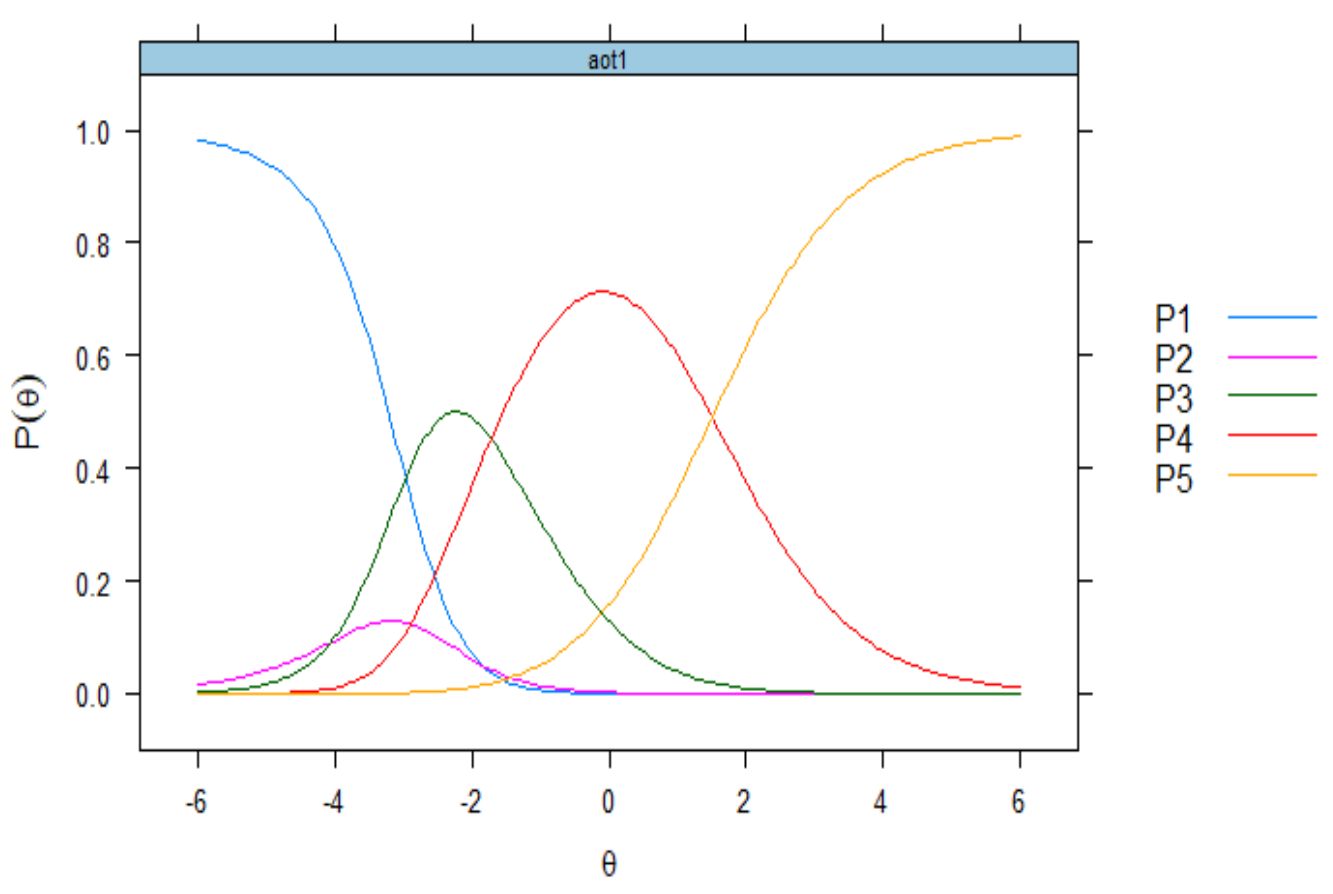

Gambar 2. Kurva karakteristik opsi butir bta1 


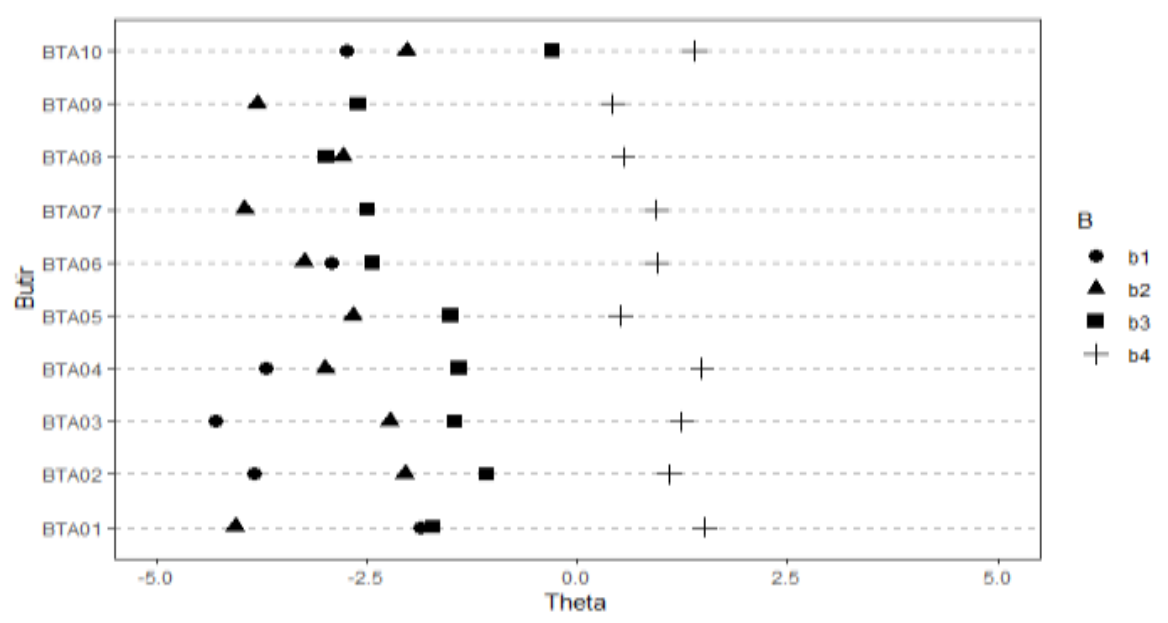

Gambar 3. Skor ambang (tingkat kesulitan) opsi butir-butir skala BTA

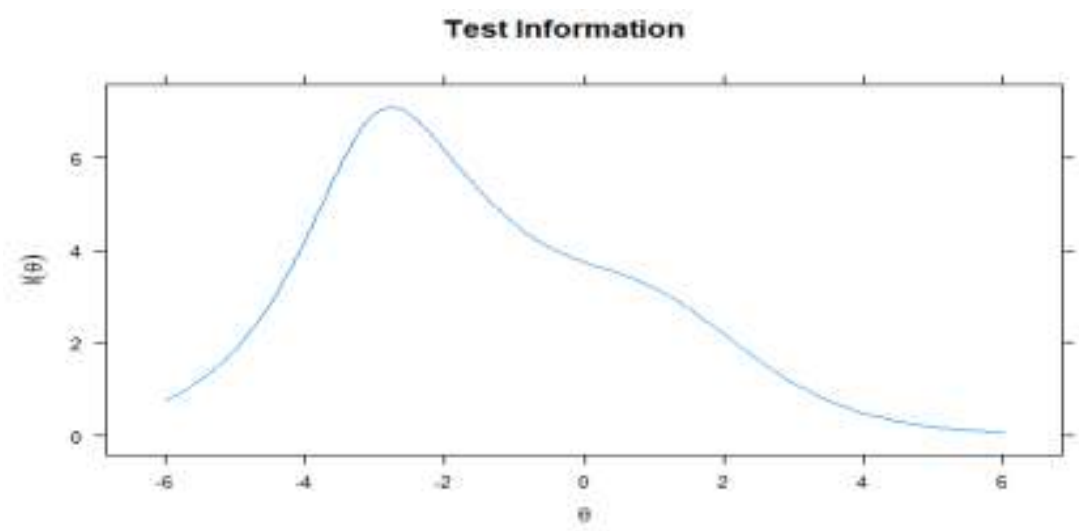

Gambar 4. Kurva informasi skala BTA

Reliabilitas dan informasi skala. Ke10 butir disposisi BTA membentuk skala dengan reliabilitas yang memadai $(0.812)$. Selain reliabilitas secara keseluruhan, analisis IRT juga menghasilkan indeks "informasi" sebagai fungsi dari skor atribut laten (theta). Seperti terlihat pada Gambar 4, skala disposisi BTA memberi estimasi dengan presisi/reliabilitas tinggi untuk responden yang memiliki skor theta antara -4 sampai 1. Untuk responden yang memiliki disposisi TBA yang kuat (skor theta di atas 1), skala ini memberi estimasi yang kurang presisi alias kurang reliabel atau mengandung relatif banyak error pengukuran.

Korelasi dengan dimensi-dimensi kepribadian. Untuk sub-sampel mahasiswa semester awal $(\mathrm{n}=228)$, korelasi bivariat menunjukkan bahwa disposisi BTA berhubungan positif dan moderat dengan sifat openness to experience $(\mathrm{r}=0.441, \mathrm{p}<0.001)$ dan conscientiousness $(\mathrm{r}=0.330, \mathrm{p}<0.001)$.

Tabel 5. Hasil regresi untuk memprediksi nilai mata kuliah Logika

\begin{tabular}{lrrrrr}
\hline \multicolumn{1}{c}{ Prediktor } & \multicolumn{1}{c}{$B$} & $S E B$ & $B$ & \multicolumn{1}{c}{$t$} & \multicolumn{1}{c}{$p$} \\
\hline Intercept & 69.844 & 1.136 & & 61.470 & .000 \\
Disposisi BTA & 4.225 & 1.356 & .230 & 3.117 & .002 \\
Conscientiousness & -2.611 & 1.995 & -.093 & -1.309 & .192 \\
Openness to experience & -.542 & 1.383 & -.029 & -.392 & .696 \\
\hline
\end{tabular}


Tabel 6. Hasil regresi untuk memprediksi IPK

\begin{tabular}{lrrrrr}
\hline \multicolumn{1}{c}{ Prediktor } & \multicolumn{1}{c}{ B } & \multicolumn{1}{c}{ SE B } & $\beta$ & \multicolumn{1}{c}{$t$} & \multicolumn{1}{c}{$p$} \\
\hline Intercept & 3.121 & .034 & & 90.698 & .000 \\
Disposisi BTA & .133 & .042 & .237 & 3.177 & .002 \\
Conscientiousness & -.038 & .060 & -.045 & -.631 & .529 \\
Openness to experience & -.066 & .042 & -.116 & -1.558 & .121 \\
\hline
\end{tabular}

Daya prediksi terhadap prestasi akademik. Regresi untuk memprediksi nilai mata kuliah Logika terbukti signifikan $(\mathrm{R}=0.211 ; \quad \mathrm{F}(3, \quad 225)=3.481 ; \mathrm{p}=0.017)$. Kaitan antara masing-masing prediktor dengan nilai Logika ditampilkan di Tabel 5. Tampak bahwa hanya disposisi BTA yang secara signifikan memprediksi nilai Logika pada sampel ini. Regresi untuk memprediksi IPK juga signifikan $(\mathrm{R}=0.209 ; \quad \mathrm{F}(3, \quad 224)=3.424 ; \mathrm{p}=0.018)$. Pada Tabel 6, sekali lagi terlihat bahwa hanya disposisi BTA yang memprediksi IPK.

\section{Pembahasan}

Disposisi berpikir terbuka secara aktif atau actively open-minded thinking (BTA) merupakan bagian dari karakter intelektual yang penting untuk Abad 21. Disposisi BTA dapat dipandang sebagai sisi afektif yang menggerakkan individu untuk berpikir secara cermat, kritis, dan mendalam. Tiga indikator yang menjadi penciri BTA adalah kesenangan mencari informasi dari berbagai perspektif, kecenderungan menunda pengambilan keputusan demi pemahaman yang lebih baik, dan kemauan merevisi atau mengubah pendapat agar sejalan dengan bukti yang ada. Penelitian ini mengevaluasi sebuah instrumen singkat yang dimaksudkan untuk mengukur disposisi BTA.

Meski cukup definisinya kompleks, disposisi BTA diasumsikan sebagai konstruk dengan dimensi tunggal (Baron, 2018; Haran et al., 2013; Stanovich \& West, 1997). Secara teknis, asumsi unidimensionalitas ini berarti bahwa variasi respon terhadap semua butir dalam skala
BTA bisa dijelaskan oleh satu atribut laten. Asumsi ini juga merupakan prasyarat bagi analisis Rasch. Hasil analisis mendukung asumsi unidimensionalitas skala BTA versi Bahasa Indonesia, terutama jika melihat scree plot serta indeks kecocokan yang dihasilkan oleh analisis faktor model 1 dimensi. Meski demikian, sebagai catatan, adanya faktor kedua yang berada pada ambang batas (nilai Eigen sedikit di atas 1), keberadaan dimensi kedua perlu menjadi perhatian dalam penelitian selanjutnya (Svedholm-Häkkinen \& Lindeman, 2018).

Analisis IRT menghasilkan nilai fit minimal 0.830 (outfit butir BTA 8) sampai maksimal 1.307 (outfit butir bta10, lihat Tabel 3). Rentang ini masih berada dalam batas yang dapat diterima untuk nilai mean-square, yakni antara 0.5 s.d. 1.5 (Lincare, 2002). Artinya, pola respon terhadap sebagian besar butir dapat dianggap sejalan dengan prediksi model Rasch. Butir-butir yang memiliki tingkat kesulitan rendah (alias "mudah disetujui") memang cenderung disetujui oleh responden yang memiliki tingkat disposisi BTA menengah sampai tinggi, serta cenderung tidak disetujui oleh responden yang memiliki disposisi BTA rendah. Sebaliknya, butirbutir dengan tingkat kesulitan relatif tinggi juga cenderung disetujui oleh responden yang disposisi BTA-nya tinggi, namun tidak disetujui responden yang disposisi BTA-nya rendah. Selain fit butir yang relatif baik, skor yang dihasilkan skala BTA juga berkorelasi positif dengan dimensi kepribadian openness to experience dan conscientiousness.

Sebagai sesama konstruk afektif, disposisi BTA bersinggungan dengan sifat 
kepribadian. Seperti diuraikan di bagian pendahuluan, secara konseptual disposisi BTA seharusnya berkorelasi positif dengan openness to experience maupun dimensi conscientiousness. Persamaan BTA dengan openness adalah bahwa keduanya menggambarkan kesenangan untuk mengetahui dan mengalami hal-hal baru. Persamaan BTA dengan conscientiousness adalah keduanya menggambarkan kemauan untuk mengendalikan impuls, meski untuk hal yang berbeda (Roberts et al., 2009). Besaran korelasi BTA dengan kedua sifat kepribadian ini sejalan dengan dugaan, yaitu moderat (antara 0.3 sampai 0.5 ) dan lebih kuat dengan openness dibanding conscientiousness.

Disposisi BTA tidak hanya berkorelasi dengan dimensi-dimensi kepribadian, tapi juga mampu memprediksi prestasi akademik. Dalam penelitian ini, prestasi akademik diukur berdasarkan dua indikator, yaitu: nilai mata kuliah Logika yang mencerminkan kemampuan spesifik terkait analisis dan evaluasi argumen, serta IPK pada akhir semester 3. Hasil regresi linear menunjukkan bahwa kenaikan 1 poin disposisi BTA terasosiasi dengan kenaikan 4.23 nilai mata kuliah Logika, serta kenaikan 0.13 poin IPK. Dengan kata lain, responden dengan disposisi BTA yang kuat (misalnya, dengan skor +2 ) akan memiliki nilai Logika sekitar 17 poin lebih tinggi dan IPK sekitar 0.5 poin lebih tinggi dibanding responden dengan disposisi BTA yang rendah (skor -2). Perbedaan ini tidak hanya signifikan secara statistik, tapi juga secara praktis.

Berdasarkan bukti-bukti di atas, skala disposisi BTA dapat dikatakan memiliki validitas konstruk yang baik. Selain itu, penelitian ini juga menunjukkan bahwa disposisi BTA berpotensi memiliki peran penting dalam proses belajar.

Namun demikian, hasil analisis IRT juga menunjukkan beberapa kelemahan yang perlu mendapat perhatian. Pertama, validitas skala dapat ditingkatkan dengan menelaah dan merevisi butir bta10 (yang pola responnya paling tidak konsisten dengan prediksi model Rasch). Butir ini berbunyi "Lebih baik bertahan pada prinsip yang kita yakini daripada berpikiran terbuka." Pola respon yang kurang konsisten terhadap butir ini mungkin terkait dengan arahnya yang berkebalikan dari ke-9 butir lainnya. Kemungkinan lainnya adalah bahwa makna butir tersebut ditafsirkan secara berbeda-beda oleh responden. Misalnya, sebagian responden mungkin menganggap bahwa frase "prinsip yang diyakini" merujuk pada keyakinan agama, sedangkan responden lain membayangkan keyakinan untuk isu-isu lain. Dalam konteks masyarakat religius, keyakinan agama memiliki arti penting tersendiri sehingga kemauan merevisi pendapat mengenai isu-isu nonagama belum tentu sejalan dengan kemauan merevisi keyakinan agama. Kemungkinan-kemunginan ini perlu dikaji lebih lanjut melalui wawancara kognitif agar perbaikan butir memiliki landasan empiris yang kuat (Castillo-Díaz \& Padilla, 2013).

Kedua, skala disposisi BTA tampaknya dapat dibuat lebih efisien dengan mengurangi butir skala yang tidak memberi informasi tambahan. Hal ini ter-lihat dari indeks fit negatif, terutama butir bta7 dan bta8 yang nilai infit serta outfit-nya di bawah -2. Dalam pemodelan Rasch, nilai fit negatif mencerminkan pola yang terlalu sesuai dengan model teoretis (overfit). Meski tidak mencederai validitas hasil pengukuran, butir yang overfit juga tidak memberi tambahan informasi (redundant). Dalam kasus ini, konten butir bta7 dan bta8 sama-sama merujuk pada preferensi untuk memahami masalah secara lebih detil atau rinci sebelum memutuskan solusinya. Dengan demikian, salah satu dari kedua butir tersebut dapat digugurkan jika ingin mendapatkan skala yang lebih efisien.

Ketiga, opsi jawaban dapat disederhanakan menjadi 4 saja. Saran ini terutama didasarkan pada temuan mengenai nilai ambang tingkat kesulitan butir (Tabel 4 dan Gamber 3). Pada butir bta5, bta7, bta8, 
dan bta9, responden tidak pernah memilih opsi paling kiri ("Sangat tidak setuju"). Pada butir-butir lain, nilai ambang antar opsi jawaban cenderung berdekatan, atau bahkan berhimpitan seperti pada butir bta1. Hanya opsi jawaban "Sangat setuju" dan "Setuju" yang nilai ambangnya memiliki jarak yang relatif jauh dari opsi lain. Hal ini merupakan indikasi bahwa perbedaan antar opsi jawaban, terutama antara "Sangat tidak setuju", "Tidak setuju", dan "Netral", tidak terlalu bermakna bagi responden. Dengan demikian, opsi jawaban sebaiknya dibuat lebih sederhana, misalnya menjadi "Tidak setuju", "Cenderung tidak setuju", "Cenderung setuju", dan "Setuju".

Keempat, perlu butir baru yang lebih bisa membedakan antar individu pada rentang disposisi BTA yang relatif tinggi. Saat ini butir-butir skala memiliki tingkat presisi atau reliabilitas yang baik pada mereka yang memiliki tingkat disposisi BTA relatif rendah (antara -4 sampai 1 theta, lihat Gambar 4). Dengan kata lain, skala tersebut kurang mampu menghasilkan skor yang presisi untuk individu yang disposisi BTA-nya relatif kuat (skor theta di atas 1), sehingga kurang bisa membedakan antara responden yang memiliki disposisi BTA kuat dan sangat kuat. Secara teknis, hal ini merupakan cerminan dari rendahnya tingkat kesulitan semua butir (relatif dibanding level disposisi BTA yang dimiliki responden).
Perlu penelitian lebih lanjut untuk mengetahui mengapa butir-butir skala BTA memiliki tingkat kesulitan yang rendah, serta untuk menghasilkan butirbutir yang lebih sulit disetujui oleh responden.

\section{Simpulan}

Hasil penelitian ini menunjukkan bahwa disposisi berpikir terbuka secara aktif dapat diukur dengan cukup akurat menggunakan skala self-report. Hasil penelitian juga menguatkan argumen bahwa disposisi tersebut merupakan komponen afektif yang penting dalam proses belajar di universitas. Perlu penelitian lebih lanjut untuk menelaah mekanisme yang menjelaskan peran disposisi berpikir terbuka secara aktif dalam konteks akademik. Untuk itu, skala yang dievaluasi dalam penelitian ini perlu dikembangkan dan diperbaiki lebih lanjut, terutama terkait tingkat kesulitan butir-butirnya.

\section{Acknowledgement}

Terima kasih kepada Dr. Ide Bagus Siaputra dan Lina Natalya, M.Si. atas bantuan dalam pengumpulan data. Penelitian didanai oleh Hibah Internal LPPM Universitas Surabaya tahun 2018.

\section{Daftar Pustaka}

Baker, F., \& Kim, S. H. (2017). The Basics of Item Response Theory Using $R$. Cham, Switzerland: Springer International.

Baron, J. (2017). Assessment of Actively Open-minded Thinking. Retrieved from http://www.sas.upenn.edu/ ba ron/papers/aotwrefs.pdf

Baron, J. (2018). Actively open-minded thinking in politics. Cognition, 188,
8-18. doi:10.1016/j.cognition.2018.1 0.004

Barzilai, S., \& Chinn, C. A. (2018). On the Goals of Epistemic Education: Promoting Apt Epistemic Performance. Journal of the Learning Sciences, 27(3), 353-389. doi:10.1080/10508406.2017.1392968

Bond, T., \& Fox, C. (2015). Applying the Rasch Model: Fundamental 
Measurement in the Human Sciences (Third Edit). New York: Routledge.

Bronstein, M. V., Pennycook, G., Bear, A., Rand, D. G., \& Cannon, T. D. (2019). Belief in Fake News is Associated with Delusionality, Dogmatism, Religious Fundamenta lism, and Reduced Analytic Thinking. Journal of Applied Research in Memory and Cognition. $8(1), \quad 108-117$. doi: 10.1016/j. jarmac.2018.09.005

Castillo-Díaz, M., \& Padilla, J. L. (2013). How Cognitive Interviewing Can Provide Validity Evidence of The Response Processes to Scale Items. Social Indicators Research, 114(3), 963-975. doi: 10.1007/s11205-0120184-8

Chalmers, P. (2012). Mirt: A Multidimensional Item Response Theory Package for The R Environment. Journal of Statistical Software, 48(6), 1-29. doi: 10.18637 /jss.v048.i06

Dwyer, C. P., Hogan, M. J., \& Stewart, I. (2014). An Integrated Critical Thinking Framework for The 21st Century. Thinking Skills and Creativity, 12, 43-52. doi: 10.1016/j.tsc.2013.12.004

Facione, P. A. (2000). The Disposition Toward Critical Thinking: Its Character, Measurement, and Relationship to Critical Thinking Skill. Informal Logic, 20(1), 61-84. doi: 10.22329/il.v20i1. 2254

Griffin, P., McGaw, B., \& Care, E. (2012). Assessment and Teaching of 21st Century Skills. Dordrecht: Springer.

Haran, U., Ritov, I., \& Mellers, B. A. (2013). The Role of Actively Openminded Thinking in Information Acquisition, Accuracy, and Calibration. Judgment and Decision Making, 8(3), 188-201. Retrieved from:http://journal.sjdm.org/13/1312 4a/jdm13124a.pdf.

Lincare, J. M. (2002). What Do Infit, Outfit, Mean-Square, and Standardized Mean? Rasch Measurement Transactions, 16(2), 878. Retrieved from: https://www.researchgate.net/ publication/305377322_What_do_inf it_and_outfit_mean-square_and_stan dardized_mean

Linacre, J. M. (1999). Investigating Rating Scale Category Utility. Journal of Outcome Measurement, 3, 103-122. Retrieved from: https://pdfs.semantic scholar.org/2d4c/958ebc9a59cf726fe 2ed1f9668ee9a40be93.pdf

Jebb, A. T., Saef, R., Parrigon, S., \& Woo, S. E. (2016). The Need for Cognition: Key Concepts, Assessment, and Role in Educational Outcomes. In Psychosocial Skills and School Systems in the 21st Century (p. 115). doi: 10.1007/978-3-31928606-8

Perkins, D. N., \& Tishman, S. (1998). Dispositional Aspects of Intelligence, 1-45. Retrieved from: Retrieved from http://learnweb.harvard.edu/alp s/ thinking/docs/Plymouth.pdf

R Core Team. (2018). R: A Language and Environment for Statistical Computing. Vienna, Austria: R Foundation for Statistical Computing. Retrieved from: https://www.r-project.org/

Richardson, M., Abraham, C., \& Bond, R. (2012). Psychological Correlates of University Students' Academic Performance: A Systematic Review And Meta-analysis. Psychological Bulletin, 138(2), 353-387. doi: 10.1037/a0026838

Roberts, B. W., Jackson, J. J., Fayard, J. V., Edmonds, G., \& Meints, J. (2009). Conscientiousness. In M. R. 
Leary \& R. H. Hoyle (Eds.), Handbook of Individual Differences in Social Behavior (pp. 369-381). New York, NY, US: Guilford Press.

Stanovich, K. E., \& West, R. F. (1997). Reasoning Independently of Prior Belief and Individual Differences in Actively Open-minded Thinking. Journal of Educational Psychology, 89(2), 342-357. doi:10.1037/00220663.89 .2 .342

Stanovich, K. E., West, R. F., \& Toplak, M. E. (2013). Myside Bias, Rational Thinking, and Intelligence. Current Directions in Psychological Science, 22(4), 259-264. doi: 10.1177/09637 21413480174

Svedholm-Häkkinen, A. M., \& Lindeman, M. (2018). Actively open-minded thinking: Development of A Shortened Scale and Disentangling Attitudes Towards Knowledge and People. Thinking and Reasoning,
24(1), 21-40. doi: 10.1080/1354678 3.2017 .1378723

Weinstein, M. (1991). Critical Thinking and Education for Democracy. Educational Philosophy and Theory, 23(2), 9-29. doi: 10.1111/j.14695812.1991.tb00129.x

Wickham, H. (2016). ggplot2: Elegant Graphics for Data Analysis. New York: Springer-Verlag.

Woo, S. E., Chernyshenko, O. S., Longley, A., Zhang, Z.-X., Chiu, C.-Y., \& Stark, S. E. (2014). Openness to Experience: Its Lower Level Structure, Measurement, and CrossCultural Equivalence. Journal of Personality Assessment, 96(1), 2945.

doi:10.1080/00223891.2013.806328

Wu, M., Tam, H. P., \& Jen, T.-H. (2016). Educational Measurement for Applied Researchers: Theory into Practice. Singapore: Springer. 